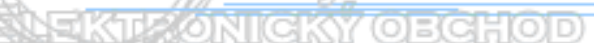

\title{
ÚLOHA ŠTÁTU PRI ZABEZPEČENÍ INTEROPERABILITY ELEKTRONICKÝCH MÝTNYCH SYSTÉMOV
}

\author{
Karol Hrudkay *
}

\section{Úvod}

Elektronický výber mýta (Electronic toll collection - ETC) je v mnohých prípadoch nosnou aplikáciou telematiky $\mathrm{v}$ doprave resp. inteligentných dopravných systémov ale aj špecifický príklad fungujúceho systému elektronického obchodu.

Vzhl'adom na historický vývoj je súčasný stav v oblasti elektronického výberu mýta $\mathrm{v}$ Európe charakterizovaný rôznymi problémami, ktoré vyplývajú predovšetkým z technologickej nejednotnosti týchto systémov, z odlišných rámcov spoplatnenia (politík a princípov spoplatnenia) ale aj z rôznych procesov a procedúr, s ktorými sa stretávajú hlavne používatelia týchto systémov, t.j. v prevažnej miere dopravcovia. Preto je dôležité sa zaoberat' zabezpečením interoperability týchto systémov v rámci celej EÚ.

Interoperabilita je definovaná ako schopnost' informačných a komunikačných systémov vymieňat' si údaje a zdiel'at' informácie a vedomosti. Z praktického hl'adiska to $\mathrm{v}$ prípade elektronického výberu mýta znamená, že palubná jednotka OBU (On-Board Unit) má vediet' komunikovat' $s$ infraštruktúrou ETC systému (presnejšie s tzv. jeho technologickou čast'ou, ktorá generuje dáta pre stanovenie správnej výšky mýta, a s enforcementom) a takisto si rozumejú aj informačné (centrálne) systémy mýtnych systémov.

\section{Dôsledky neriešenia interoperability}

Dôsledkom uvedených skutočností sú problémy prevažne na strane používatel'ov mýtnych systémov. Tie sa prejavujú prakticky ako časové straty vyvolané povinnost'ami používatel'ov v súvislosti s registráciou do mýtnych systémov, pričom tieto zmluvné záväzky vyvolávajú aj dodatočné finančné náklady, viazanie nemalých finančných prostriedkov a pod. Netreba zabúdat' aj na iný dôležitý faktor neriešenia interoperability mýtnych systémov a to je bezpečnost'. Neriešenie interoperability sa potom premietne do povinnosti mat' vo vozidle viacero zariadení na výber mýta - palubných jednotiek (OBU), čo môže zhoršovat' výhl'ad vodičovi, odpútavat' pozornost' a prípadne si vyžadovat' aj jeho zásah (napríklad pri prekročení oblastí mýtneho systému - spravidla hraníc, čo v prípade existencie schengenského priestoru vyvoláva dojem akýchsi elektronických hraníc).

Ako to z hl'adiska procesného vyzerá medzi skupinami subjektov používatel'ov a spoplatňovatel'ov $\mathrm{v}$ prípade neriešenia interoperability ukazuje obrázok $1 \mathrm{a}$. V tomto prípade musí používatel' uzatvorit' zmluvu s každým spoplatňovatel'om resp. prevádzkovatel'om elektronického mýtneho systému, na ktorého oblasti plánuje realizovat' výkony. Každému jednému zmluvnému vzt’ahu potom odpovedá aj finančné plnenie (je nateraz jedno či sa platí vopred - prepaid alebo na faktúru - postpaid).

\footnotetext{
* Ing. Karol Hrudkay, Výskumný ústav dopravný, a.s., Vel'ký Diel 3323, Žilina tel.: +421 415686 337, fax: +421 415652883

e-mail: hrudkay@vud.sk
} 


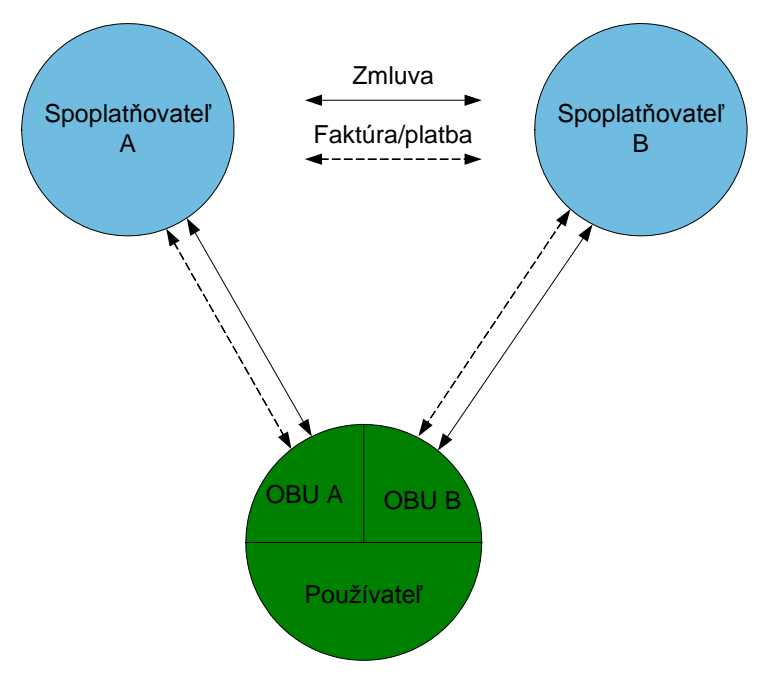

a)

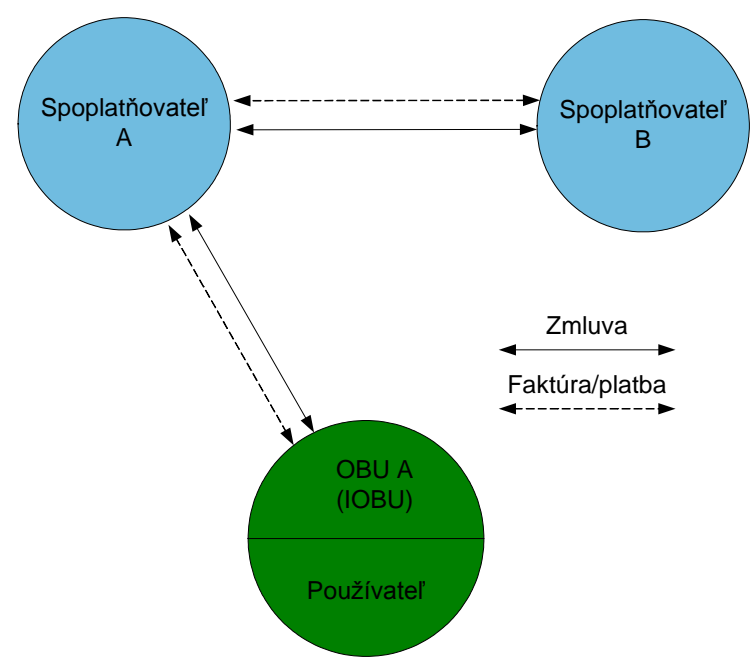

b)

Obr. 1 Zjednodušený vzt'ah používatel' - spoplatňovatel': a) neriešená interoperabilita, b) adhoc riešenie interoperability (prípad jedna OBU, jedna zmluva)

\section{Európsky rámec pre interoperabilitu}

Základným rámcovým dokumentom pre interoperabilitu ETC systémov v EÚ je Smernica 2004/52/ES o interoperabilite elektronických cestných mýtnych systémoch v Spoločenstve. Ciel'om Smernice je teda interoperabilita ETC systémov v Európe, ktoré sú založené na verejných normách a nediskriminačnom princípe.

Z hladiska používatel'a naplnenie tohto zámeru potom znamená, že pri realizácii dopravných výkonov v rámci Spoločenstva mu bude postačovat’:

- $\quad$ uzatvorit' jednu zmluvu,

- $\quad$ používat' iba jednu OBU,

- $\quad$ za tieto služby obdrží jedinú faktúru resp. zrealizuje jednu platbu vopred (pozn. požiadavka na vystavenie jednej faktúry nie je striktne uvedená v Smernici, čiže nie je to striktná legislatívna požiadavka, vyplýva to iba z používatel'ského pohl'adu na interoperabilitu).

Takýto príklad je zobrazený na obrázku 1b. Používatel' má zmluvný vzt'ah s jedným spoplatňovatel'om, ktorý mu poskytne takú palubnú jednotku, ktorú môže používat' v rámci oblastí oboch spoplatňovatel'ov, pričom platobný vzt'ah je taktiež iba s jedným spoplatňovatel'om.

Príklady z praxe sú síce založené na použití jednej interoperabilnej OBU (IOBU), no potrebné sú viaceré zmluvné vzt'ahy používatel'a. V prípade dvojstrannej (tzv. bilaterálnej) interoperability používatel' má možnost' používat' iba jednu OBU, zmluvy musí mat' však uzatvorené s oboma spoplatňovatel'mi. V praxi ide o interoperabilitu medzi Rakúskom a Švajčiarskom (iba jedným smerom, švajčiarska OBU môže byt' použitá v rámci rakúskeho systému, pretože švajčiarsky systém je principiálne založený na stanovovaní prejdenej vzdialenosti podl'a údaja tachografa a mikrovlnové rozhranie slúži iba na detekciu prechodu hraníc čím OBU ,zapne/vypne“ meranie prejazdenej vzdialenosti - toto mikrovlnové rozhranie však vyhovuje rakúskej špecifikácii), Rakúskom a Talianskom (musí íst' o OBU, ktorá je schopná komunikácie v oboch systémoch - tzv. duálna OBU, pretože taliansky systém má inú špecifikáciu ako iné mikrovlnové systémy založené na štandardoch CEN) a Francúzskom a Španielskom. Problémy interoperability bolo v niektorých prípadoch potrebné vyriešit' aj na národnej úrovni, nakol'ko v rámci jednej krajiny existovalo viacero (aj desiatky) spoplatňovatel'ov s neinteroperabilnými systémami (napr. Taliansko, Francúzsko, Španielsko). 
To, že problém interoperability je nielen technickým problémom, ale predovšetkým zmluvným (a teda aj ekonomickým) ukazujú zasa iné príklady ako je napr. neuzatvorená interoperabilita Rakúsko - Česko, a to napriek tomu, že systémy používajú rovnaké štandardy a sú od rovnakého dodávatel'a (odlišné sú iba transakcie). V krátkom čase by sa mala dosiahnut' aj interoperabilita medzi Rakúskom a Nemeckom, no iba v jednom smere, t.j. nemeckú OBU bude možné použit' v rakúskom systéme, naopak to nebude možné, rakúska OBU je mikrovlnová, nemecký systém satelitný (tento prípad sa rieši už od r. 2006). Vo všeobecnosti platí, že napriek týmto dosiahnutým výsledkom je bilaterálna interoperabilita pomerne málo medzi používatel'mi využívaná a to predovšetkým pre povinnost' uzatvorit' separátne zmluvy s oboma spoplatnitel'mi.

Pozitívnymi príkladmi sú aj výsledky mnohých európskych projektov, ktoré prakticky poukázali na možnosti riešenia interoperability, väčšinou na území určitého regiónu. Napr. projekt RCI sa zaoberal interoeprabilitou na území Nemecka (Toll Collect), Švajčiarska (LSVA), Francúzska (TIS-PL), Španielska (VIA-T), Talianska (TELEPASS) a Rakúska (ASFINAG), iniciatíva mýtnych operátorov $\mathrm{z}$ alpského regiónu MEDIA (Rakúsko, Francúzsko, Taliansko, Slovinsko) sa venovala implementácii konkrétneho interoperabilného riešenia založeného na mikrovlnovej technológie (DSRC).

\section{Smernica o interoeprabilite a EETS}

Oblast'ou pôsobnosti Smernice sú systémy elektronického výberu mýta, ktoré si vyžadujú použitie OBU, pričom pokrýva výber všetkých typov cestných poplatkov na celej cestnej sieti v EÚ (t.j. celej cestnej sieti, kde sa vyberá mýto elektronicky) a rôznych cestných objektov (napr. mosty, tunely, trajekty). Naopak nemusí sa uplatnit' na malé (lokálne) systémy, kde by riešenie interoperability bolo zjavne neekonomické príp. diskriminačné.

Na základe Smernice môže Európska komisia implementovat' opatrenia, ktoré sa môžu ukázat' ako nevyhnuté na zabezpečenie interoperability sietí. Treba poznamenat', že Smernica bola do slovenskej legislatívy prebraná zákonom o elektronickom výbere mýta č. 25/2007 Z.z.

Smernica priamo definuje, že ETC systémy uvedené do prevádzky po 1.1.2007 musia používat' aspoň jednu z nasledujúcich technológií:

- $\quad$ mikrovlnová technológia (DSRC),

- $\quad$ satelitné určovanie polohy (GNSS t.j. v súčasnosti GPS, perspektívne Galileo),

- mobilná komunikácia GSM-GPRS,

pričom jednoznačne odporúča použit' satelitnú technológiu, t.j. GNSS/CN (Smernica pre mobilnú komunikáciu priamo menuje štandard GSM-GPRS TS 03.60/23.060, pričom v ostatných dvoch prípadoch je vyhradenie technológií iba slovné „satelitné určovanie polohy“ resp. „5,8 GHz mikrovnová technológia“).

V princípe teda Smernica pripúšt’a existenciu ETC systémov založených na dvoch odlišných (no snád' komplementárnych) technológiách a to mikrovlnových a satelitných. Dôsledkom toho je, že interoperabilná palubná jednotka (IOBU) musí byt' potom vybavená všetkými troma technológiami. Momentálne tomuto kritériu vyhovuje OBU nemecká a slovenská (niekedy sa nesprávne aj švajčiarsky systém označuje ako satelitný, no ten je primárne založený na stanovení mýta podl'a tachografu a najviac nevyužíva mobilnú komunikáciu). Perspektívne takáto OBU bude dostupná i v Česku, kde sa bude rozširovat' mýtny systém práve o satelitnú čast' (pozn. principiálne takéto OBU splňujú požiadavky Smernice, no z praktického hl'adiska je potrebné poznamenat', že takejto OBU bude pre celoeurópsku interoperabilitu stále chýbat' jedno rozhranie a to pre taliansky mikrovlnový štandard UNI).

Smernica taktiež, mimo striktne vymenované technológie, pripúšt’a použitie aj iných technológií, tieto však nesmú viest' k diskriminácií, umožňuje aj prepojenie s tachografom. Kladie taktiež dôraz na ochranu osobných údajov. 
Európska elektronická mýtna služba EETS (European Electronic Toll Service) je priamo zriadená uvedenou Smernicou. Je charakterizovaná ako doplnok národných ETC systémov. Táto služba zaručuje interoperabilitu existujúcich („starých“) ETC systémov ale aj budúcich.

Služba je založená na princípe, že zmluva s ktorýmkol'vek poskytovatel'om EETS služby bude znamenat' prístup k tejto službe na celej sieti. Smernica predpokladala presnú charakteristiku EETS, ktorá mala byt' zverejnená do 1.7.2006 a od tohto dátumu mala byt' služba dostupná do 3 rokov pre nákladné (úžitkové) vozidlá nad 3,5 tony resp. vozidlá s viac než 9 miestami na sedenie a do 5 rokov pre všetky ostatné vozidlá.

EETS je nezávislá od podmienok výberu mýta (napr. kategorizácia vozidiel, výška poplatkov, ...), v tomto sa zachováva tzv. princíp subsidiarity členského štátu. Týka sa iba metódy výberu mýta. Ak to bude pre použivatel'a potrebné, EETS prevádzkovatel' poskytne vhodnú palubnú jednotku, ktorú v tomto prípade označujeme ako EOBU (musí používat' vyššie uvedené technológie, musí byt' schopná komunikovat' vo všetkých ETC systémoch v rámci Spoločenstva a musí mat' implementovanú EETS). Zjednodušený model EETS služby je uvedený na obrázku 2a.
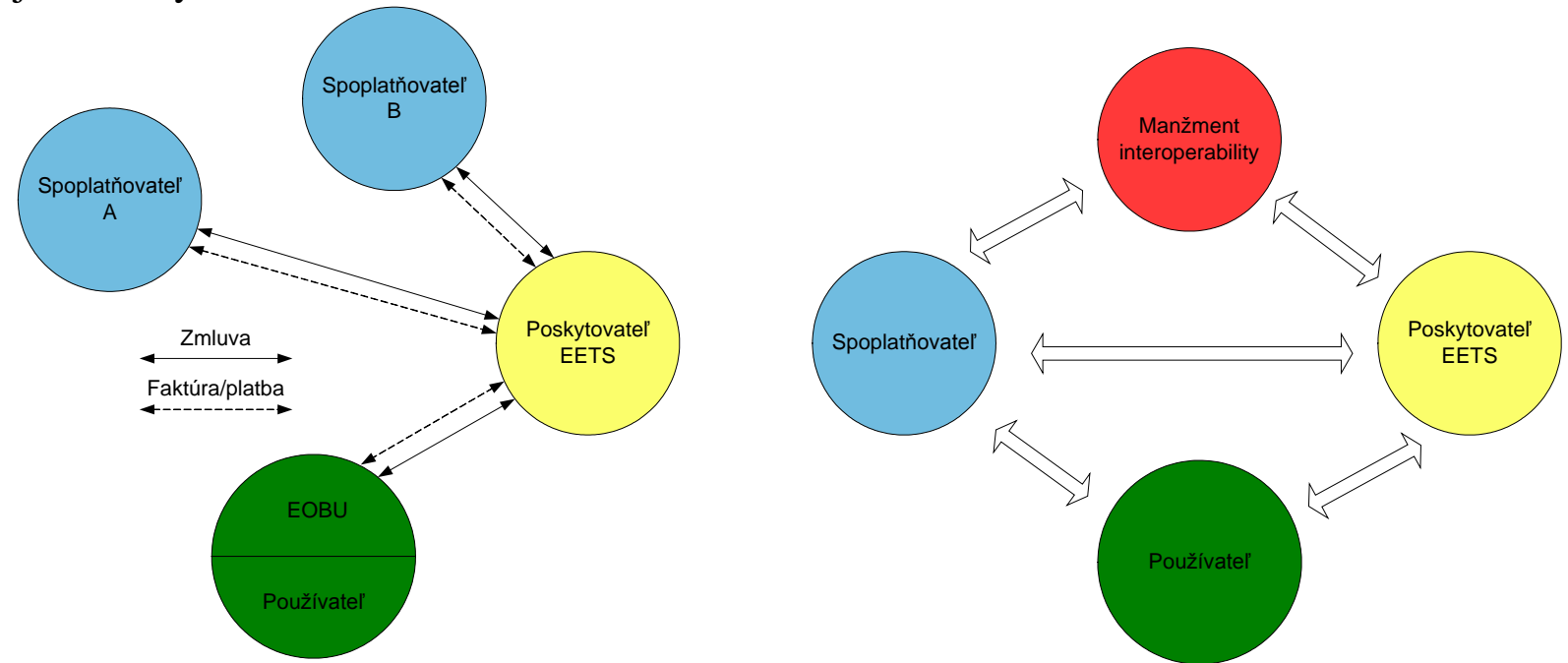

Obr. 2 Model EETS interoperability 2a) z pohl'adu používatel'a, 2b) všeobecný model

Pri takejto koncepcii používatel' uzatvorí zmluvu iba $\mathrm{s}$ jedným (ktorýmkol'vek) pokytovatel'om EETS, ktorý mu v prípade potreby poskytne aj EOBU a voči ktorému si potom plní aj svoje finančné povinnosti.

Rozhodnutie o definícii Európskej služby elektronického výberu mýta a jej technických prvkov (2009/750/ES) bolo zverejnené v Úradnom vestníku EU až 13.10.2009, čiže očakávaná definícia mešká oproti predpokladom viac než 3 roky.

Rozhodnutie zdôrazňuje všeobecné princípy, na ktorých je EETS založená, ktoré sú:

- $\quad$ jediná OBU (tzv. EOBU) sa môže požívat' vo všetkých oblastiach EETS - jediná OBU je fundamentom interoperability, no takúto EOBU bude možné využit' iba $\mathrm{v}$ ETC systémoch začlenených medzi oblasti EETS (t.j. spadá do pôsobnosti Smernice),

- $\quad$ EETS je založená na spravodlivom stanovení cien,

- $\quad$ EETS je doplnkovou službou k národným (lokálnym) systémom, t.j. režim, ktorý poznáme dnes napr. na národnej úrovni bude zachovaný, pribudne len možnost' zriadit' si EETS,

- $\quad$ zaistia sa interoperabilné prostriedky na kontrolu správneho vykázania mýta (interoperabilné cezhraničné prostriedky vymáhania tzv. enforcementu), 
- $\quad$ potrebné technické špecifikácie pre zložky a rozhrania ETC systémov budú vychádzat' zo štandardov poverených európskych štandardizačných orgánov,

- $\quad$ spoplatňovatel' môže byt' poskytovatel' EETS (za určitých podmienok ako napr. oddelené účtovníctvo a zákazu krížových dotácií).

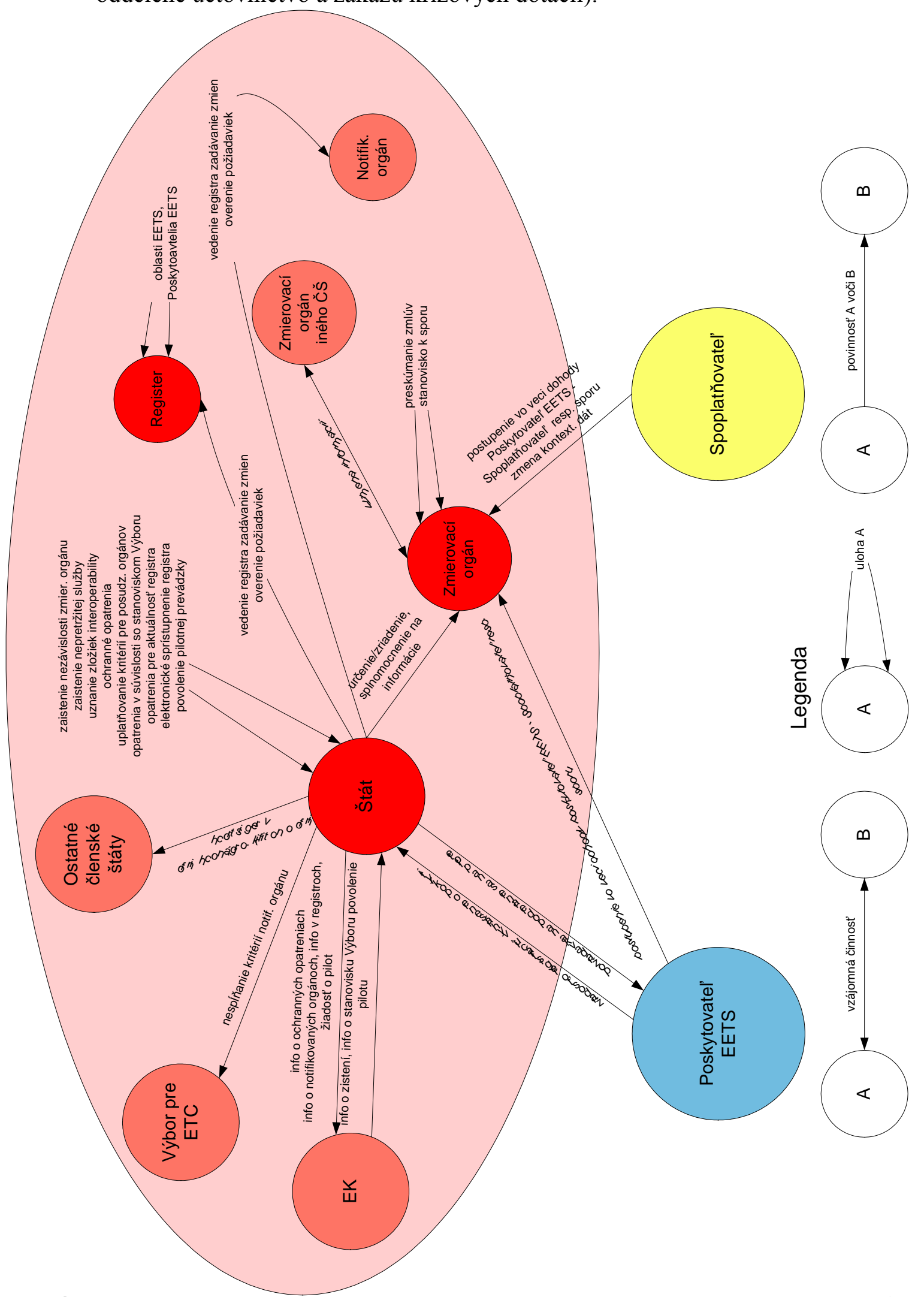

Obr. 3 Úlohy členského štátu v systéme zabezpečenia interoperability ETC systémov v EÚ 


\section{Úloha štátu}

Model interoperability (obr. 2b) bol definovaný projektom CESARE (Common Electronic Fee Collection System for a Road Tolling European Service). Z praktického hl'adiska bola úloha manažéra interoperability spomínaným Rozhodnutím rozdelená medzi viacero subjektov, v princípe medzi členské štáty EÚ a EK.

Úlohy štátu možno sektorovo rozdelit' na:

- $\quad$ povinnosti samotného štátu (štát zriad’uje zmierovací orgán a vedie register),

- $\quad$ povinnosti voči subjektom na trhu ETC (poskytovatel' EETS, spoplatňovatel') a

- $\quad$ povinnosti voči zahraničným orgánom a subjektom (ostatné členské štáty, EK).

Jednotlivé úlohy štátu sú zobrazené na obr. 3. a je z nich zrejmé, že štát bude mat' významné kompetencie ako regulátor trhu pre oblast' interoeprability ETC v príslušnom štáte. Je to však na druhej strane aj potenciálne riziko, pretože na jednotnom trhu (t.j. poskytovania jednotnej EETS služby) bude vystupovat' viacero takýchto subjektov, t.j. členských štátov.

Pre viaceré povinnosti členského štátu Rozhodnutie o EETS definuje aj požiadavku na časové plnenie (tab. 1).

Tab. 1 Časový rámec plnenia úloh štátom

\begin{tabular}{|l|l|}
\hline Termín fixný (od 8.10.2009) & Poznámka \\
\hline Do 9 mesiacov & Dostupný register \\
\hline Do 3 rokov & Zabezpečia ponúkanie EETS pre NV a BUS \\
\hline Do 5 rokov & Zabezpečia ponúkanie EETS pre všetky ostatné vozidlá \\
\hline
\end{tabular}

\begin{tabular}{|l|l|}
\hline Termín (priebežný) & Poznámka \\
\hline Do 1 mesiaca* & Rozhodnutie, či má všetky doklady potrebné pre sprostredkovanie \\
\hline Do 6 mesiacov* & Vydá stanovisko k sporu \\
\hline $\begin{array}{l}\text { Hned' po zadaní parametrov } \\
\text { vozidla }\end{array}$ & Zaistí nepretržitú službu (bez zásahu človeka) \\
\hline Bezodkladne & $\begin{array}{l}\text { Informuje EK o prijatých opatreniach (zložky interoperability } \\
\text { nespíňajú požiadavky EETS) }\end{array}$ \\
\hline Čo najskôr & Zainteresovanej strane oznámi dôvody rozhodnutia \\
\hline Bezodkladne & Stiahne súhlas daný orgánu, ktorý nesplńa kritériá na notifikáciu \\
\hline Do 3 mesiacov & $\begin{array}{l}\text { Postúpi Výboru pre elektronický výber podozrenie, že orgán } \\
\text { notifikovaný iným ČŠ nesplńa kritériá }\end{array}$ \\
\hline Ihned' po prijatí & Zadáva zmeny do registra spoplatňovatel'ov \\
\hline Aspon̆ raz ročne & Overuje požiadavky na poskytovatel'a EETS \\
\hline Koniec kalendárneho roka & $\begin{array}{l}\text { Oznámi ostatným ČŠ a EK registre oblastí EETS a poskytovatel'ov } \\
\text { EETS }\end{array}$ \\
\hline Na max. 3 roky & Vydá povolenie na pilotný mýtny systém \\
\hline$*$ Zmierovací orgán &
\end{tabular}

* Zmierovací orgán

\section{Záver}

Európska komisia a pracovná skupina Výboru pre elektronický výber mýta (Electronic Tool Committee) pripravia návod na aplikáciu menovanej Smernice a Rozhodnutia o definícií EETS. Tieto dva dokumenty formujú rámec pre EETS a je možno konštatovat', že tento je pripravený, všetky konkrétne prevádzkové otázky si však musia riešit' účastníci (subjekty) zainteresované do riešenia interoperability elektronického výberu mýta medzi sebou. Európska komisia bude implementáciu EETS nad'alej monitorovat' a po 18 mesiacoch vypracuje správu o pokroku v oblasti zavádzania EETS. Až praktický pokrok v oblasti implementácie interoperability časom ukáže, či rámec je definovaný dostatočne, či proces prebieha správnym smerom a dostatočne rýchlo, alebo sú potrebné d'alšie regulačné zásahy. 
V procese zabezpečenia celoeurópskej interoperability elektronických mýtnych systémov v Európe bude hrat' vel'mi dôležitú rolu každý členský štát EÚ. Vzhl'adom na predpokladané časové plnenia pre jednotlivé povinnosti štátu, je potrebné čo najskôr sa vážne zaoberat' zabezpečením všetkých potrebných úkonov tak, aby SR bola včas a kvalitne pripravená na celoeurópsku interoperabilitu.

\section{Literatúra}

[1] HRUDKAY, K.: Dopad Smernice o interoperabilite a Rozhodnutia o EETS na dopravcov, Pripravenost' slovenského mýtneho systému na interoperabilitu, workshop, Bratislava, 17.5.2010, ISBN 978-80-970427-0-7

[2] Smernica 2004/52/ES o interoperabilite elektronických cestných mýtnych systémov v spoločenstve

[3] Rozhodnutie EK o definícii Európskej služby elektronického výberu mýta a jej technických prvkov 2009/750/ES

[4] -: Správy projektu CESARE, www.cesareiv.eu 